\title{
Cultural Enthusiasm, Resistance and the Societal Embedding of New Technologies: Psychotropic Drugs in the 20th Century
}

\author{
FRANK W. GEELS*, TOINE PIETERS** \& STEPHEN SNELDERS** \\ *Eindhoven University of Technology, ${ }^{* *} V U$ Medical Center Amsterdam, Department of Medical Humanities \\ (Metamedica), Amsterdam, The Netherlands
}

\begin{abstract}
The societal embedding of new (medical) technologies involves not only market success, but also regulation and public acceptance. Cultural enthusiasm about their benefits and social concerns about their risks and dangers are in this respect important. Conceptualizing interactions between product championing, cultural enthusiasm and resistance, the article analyses three patterns of societal embedding: (1) hype-cycle, (2) contested embedding, and (3) controversy and stalemate. A fourth pattern of waves of enthusiasm and concern is proposed for technologies with unexpected side effects. This pattern is explored and elaborated with a longitudinal case study of the introduction of a particular form of medical technology: psychotropic drugs such as Veronal and Valium in the period 1900-2000.
\end{abstract}

\section{Introduction}

New technologies not only need integration in relevant industries and markets, they also need broader societal embedding. Deuten et al. ${ }^{1}$ distinguished three dimensions of societal embedding:

(1) Integration of new products in relevant industries and markets. Embedding in existing practices and cultural repertoires of users may be required.

(2) Acceptance by the wider public and fitting with societal norms and beliefs, indicated by three conditions: (i) the new product is actually used, (ii) resistance and societal concern are not overly large, (iii) there has been sufficient articulation of the pros and cons so that choices can be consciously made.

(3) Admissibility of new products according to the rules and standards set by government agencies or sectoral bodies. 


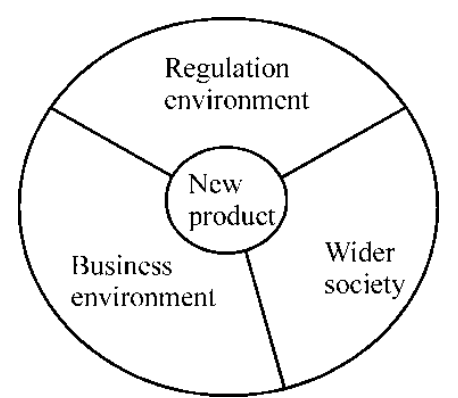

Figure 1. Relevant environments for new products. Source: Deuten et al. (Ref. 1, p. 134)

While the first dimension refers to economic viability, the second and third dimension refer to socio-cultural legitimacy. Framed in another way, Deuten et al. distinguish three environments in which new products need to function (Figure 1). Actors in the business environment have input-output relations with the innovator (e.g. suppliers, customers, research institutes). Actors in the regulation environment are different kinds of governmental and regulatory bodies. Actors in the wider society are consumer organizations, environmental groups, public opinion leaders, media, independent scientists, etc.

Development and embedding of new technologies require the alignment of all three dimensions and environments. Most innovation theories, however, focus on the business environment, sometimes complemented with the regulations environment. Public acceptance and the wider society are often left to historians of technology and cultural studies scholars. ${ }^{2}$ This way scholars keep reproducing the separated research traditions that Jamison and Hård distinguished in a recent TASM issue: ${ }^{3}$ (a) entrepreneurial innovation, (b) (social-) construction of science and technology, and c) cultural appropriation, e.g. ethical debates, public discourses, belief systems and cultural symbols.

This article aims to build bridges between these research traditions, focusing on interactions between promises by product champions, cultural enthusiasm, social concerns and regulations. The research question is: how do these interactions result in different trajectories of societal embedding of new technologies?

Section 2 addresses this question theoretically, combining research on early promises and early warnings with insights about cultural enthusiasm and resistance. This results in three patterns of societal embedding and a hypothesized fourth pattern. Section 3 further explores this fourth pattern with a case study of the introduction and use of a particular medical technology in the 20th century: barbiturates and benzodiazepines, psychotropic drugs that were used as hypnotics and tranquillizers. Psychotropic drugs have been focal points of cultural enthusiasm in the public sphere as well as loci of public contestation. The emergence of unexpected side effects has especially endangered the process of embedding these drugs and turning them into everyday commodities.

\section{Patterns in Societal Embedding of New Technologies}

New technologies are often first used in small market niches or subsidized technological niches. ${ }^{4}$ These niches form protected spaces for testing and further technical development. Societal attention is usually limited, because of the sheltered character of developments. An exception to this rule is when the first applications are eye-catching, e.g. races in 
the late 1890s with new kinds of automobiles, ${ }^{5}$ spectacular electric lighting at fairs and shows, ${ }^{6}$ or the sweeping rush of the wondrous new technology of X-rays into use for medical diagnosis and therapy at the turn of the 20th century. ${ }^{7}$ Subsequent diffusion tends to follow a trajectory of niche-accumulation, with the technology being used in increasingly larger market niches (Figure 2).

In this conceptualization, societal embedding has linear characteristics and seems market driven. However, the process becomes more complex if market niches are not waiting 'out there', but need to be actively created. New technologies, markets, user preferences and regulations are often co-constructed. ${ }^{8}$ Co-construction is a multi-actor process, with both producers and users as important agents of technological change. The prospect of commercial, medico-scientific and broader social applications creates incentives to explore new ways of designing, modifying, selling, domesticating or resisting technologies.

While early niche-activities may fall within the scope of individual entrepreneurs or spokespersons the jump to larger application domains requires more resources and collective action. Hence, innovators, entrepreneurs or health advocates try to attract attention from sponsors and lobby to create a favourable regulatory environment. Story telling, the articulation of positive promises but also early warnings are important mechanisms in this phase of technological innovation. ${ }^{9}$ Product champions make optimistic, but diffuse promises about future performance, societal benefits and profits. They give presentations, distribute reports with positive findings, go to conferences and talk to the press to create an optimistic atmosphere around the new technology. If these promises are accepted and stabilize into an agenda, venture capitalists, governmental or non-governmental sponsors may create programmes to sponsor further research and development activities. Perez ${ }^{10}$ argued that the mobilization of capital is a crucial step in technological revolutions. Promises and enthusiastic scenarios are one way to achieve this. For sciencebased technologies, medical technologies par excellence, entrepreneurs often rhetorically use the breakthrough metaphor, presenting particular innovations as crucial steps that deserve lavish funding. ${ }^{11}$

Insiders (whether on the part of producers or users) articulate promises or warnings in the early phase of societal embedding. They focus on the steps they deem necessary to articulate possibilities or overcome perceived problems. The forecasts are in general optimistic, anticipating success and avoiding consideration of obstacles. If controversies exist within scientific and technological communities, these are downplayed towards the outside world of sponsors, regulators, users and the media.

How does society react to these early promises and warnings around new technologies? While the previous sections focused on 'internal' innovator dynamics, the answer to this question requires the mobilization of broader cultural studies' notions. Cultural histories

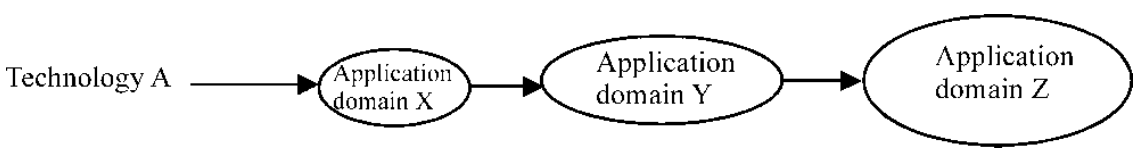

Figure 2. Diffusion as trajectory of niche-accumulation. Source: D. A. Levinthal, The slow pace of rapid technological change: gradualism and punctuation in technological change, Industrial and Corporate Change, 7(2), 1998, pp. 217-247 (see p. 243) 
of technologies have shown that reactions in the public sphere are often framed in terms of enthusiasm and/or resistance. ${ }^{12}$ The two opposite types of reactions have deep historical roots in the Enlightenment and Romanticism. Generally speaking, Enlightenment thinkers saw science and technology as the best means to achieve societal progress. New technologies should be welcomed as allies for building a better world. Romanticism, on the other hand, was a revolt against early industrialization, decrying the 'dark satanic mills' of industrial cities (William Blake). Romantics were sceptical of new technologies and concerned about negative influences and side effects. This is nicely exemplified by Mary Shelley's 19th century story of Frankenstein, which has remained a compelling vehicle for collective anxieties about the effects of new technologies. ${ }^{13}$

The ambivalence about the fortunes of progress is deeply engrained in Western cultures. Public debates about new technologies often follow a mixed pattern of enthusiasm and resistance. ${ }^{14}$ This 'two-track approach' also has institutional roots, with enthusiasm being institutionalized in Ministries of Economic Affairs that promote innovation and concern being institutionalized in Ministries of Social or Environmental Affairs that regulate side effects. ${ }^{15}$

Possible reasons for promise and hope are: (a) new technologies may create new horizons (e.g. in terms of health and disease, welfare or logistics), (b) new technologies may help solve particular every day life problems, (c) new technologies may link up with broader cultural developments (e.g. the introduction of washing machines as part of the mechanization of the household). Possible reasons for warning and resistance are: (a) new technologies may have direct negative effects, e.g. for local residents or for actors with vested interests in another technology (e.g. waste disposal), (b) new technologies may have a high risk perception value (e.g. nuclear power plants or genetically modified organisms), (c) new technologies may have unexpected side effects that cannot be foreseen (e.g. chemicals and pharmaceuticals), (d) new technologies may have a mis-match with existing norms, leading to moral anxiety (e.g. cloning).

Using enthusiasm and resistance as extremes on a continuum, we distinguish three kinds of societal reactions to the promises of new technologies: (i) cultural enthusiasm, (ii) both enthusiasm and resistance, (iii) controversy and resistance. These reactions result in three different patterns of societal embedding, which are discussed below.

\subsection{Hype-Cycle}

According to this pattern, the putative or implicated users and the wider public buy into product champions' promises, reacting optimistically to new technologies. When the age-old dream of flying materialized in the early 20th century, people reacted with amazement and enthusiasm. Cultural enthusiasm took the form of a 'winged gospel' and visions about the coming 'air age', in which the aircraft would change society for the better. ${ }^{16}$ There were promises of mass personal flying, with prophets writing enthusiastically about an 'airplane in every garage'. People could live in the countryside and fly to work in the morning. Airplanes became part of iconographies of future cities, promising personal freedom (Figure 3).

This example illustrates that cultural enthusiasm takes the form of broad visions, dreams of a new age, promises of societal transformations for the better, utopias. Similar forms of enthusiasm occurred with radio, film and with therapeutic discoveries. ${ }^{17}$ Cultural enthusiasm is articulated in magazines, newspapers, radio or television programmes and by 


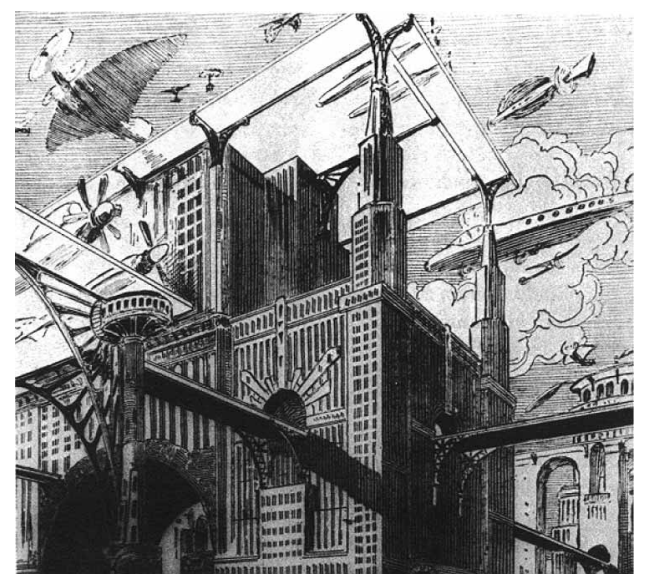

Figure 3. Frank Paul, illustrations for Earl Bell's, 'The moon doom', Amazing Stories, Winter, 1928. Source: C. Willis, skyscraper utopias: visionary urbanism in the 1920s, in: J. J. Corn (Ed.), Imagining Tomorrow: History, Technology and the American Future (Cambridge, MA: The MIT Press, 1986), pp. 164-187 (see p. 180)

other media means. Producers, mediators and consumers actively take part in this articulation process, thereby snowballing the message of promise and hope.

In their analysis of pitfalls in technological forecasting, Geels and Smit ${ }^{18}$ found that early promises are usually inflated and are adjusted over time. Rather than blaming this on, for instance, the short-sightedness of forecasters, they interpreted the inflation of early promises as a common mechanism in technological development, used instrumentally by entrepreneurs to attract attention and venture capital. This results in a particular pattern of societal embedding, the hype-cycle, developed by Gartner consultancy and Snelders et al. ${ }^{19}$ Depending on the context, the hype-cycle may consists of three or more phases (Figure 4):

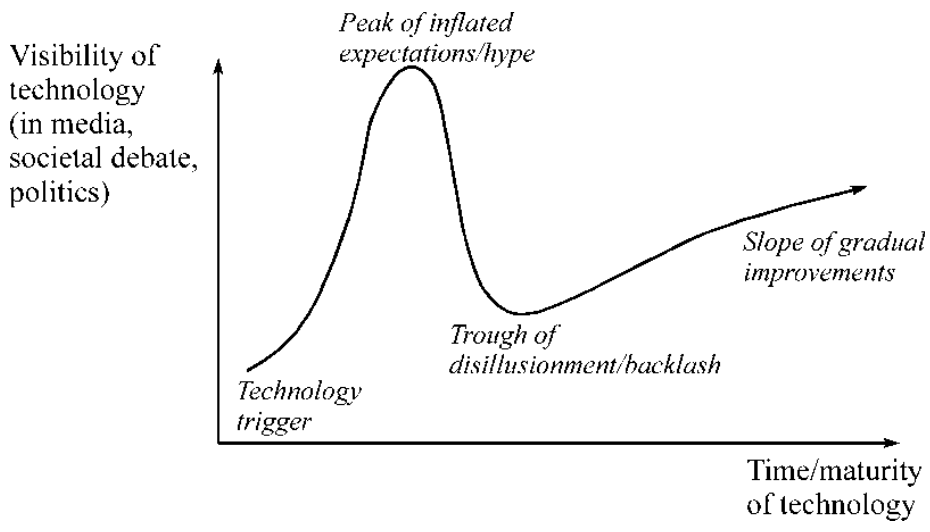

Figure 4. The hype-cycle. Source: Gartner.com (accessed 15 March 2005) 
(i) Technology trigger: presentations and positive reports about a new technology generate press and industry interest;

(ii) Peak of inflated expectations: science and technology leaders and product champions raise high expectations about new uses, performance and functionality, leading to over-enthusiasm and unrealistic expectations;

(iii) Trough of disillusionment: there are some successes with the new technology, but more failures; the technology does not live up to its inflated expectations and it rapidly becomes unfashionable; enthusiasm makes way for resistance in the press. In the process the technology may be shelved;

(iv) Slope of gradual improvements: ongoing work by technology developers leads to improved understanding of the technology's applicability, risks and benefits. Commercial off-the-shelf methodologies and tools become available and real-world benefits are demonstrated and accepted. This leads to gradual market penetration and renewed enthusiasm. The technology is integrated in daily life. As the technology becomes taken for granted, the visibility in the public sphere fades (not represented in Figure 4).

Cultural enthusiasm provides a positive context for societal embedding, with no substantial resistance. If technical disagreements exist within the technical community, these are not widely communicated to the outside world, but dealt with internally. During the 'trough of disillusionment' controversy spreads but is to a large extent linked to the disappointing speed of technological development, not to negative effects.

\subsection{Contested Embedding}

In this pattern, some societal groups, often lead-users, react enthusiastically to the new technology, while other societal groups, who experience immediate negative effects, react negatively. Early cars, for example, were used by rich urbanites for racing and for touring in the countryside. Car races were very popular in the late 1890s, attracting many spectators and press interest. They linked up positively with cultural values such as interest in excitement and danger, physical prowess, elite status, masculine courage, aggressiveness and striving for records. ${ }^{20}$ Touring in the countryside was popular with users, who enjoyed the freedom and flexibility to choose their own routes (in contrast to train and tram), but there was protest besides enthusiasm. Accidents happened frequently, killing pedestrians and livestock. Farmers also suffered from dust waves created by speeding cars. To oppose automobiles, some farmers ploughed roads to make them unsuitable and lobbied for bans to prohibit cars from using rural roads. ${ }^{21}$ Opposition also came from urban anti-speed organizations that worried about increasing numbers of fatal accidents with pedestrians.

In this pattern, the societal embedding of new technologies is contested. Experiencing effects differently, social groups may have different interpretations of technology's meaning. Farmers saw early cars as 'devil wagons', while rich urbanites saw 'adventure machines'. ${ }^{22}$ This contestation and interpretative flexibility is a common phenomenon in technological development. ${ }^{23}$ Although opposition by specific groups not always reflects wider public resistance, it may gradually undermine the legitimacy of new technologies, especially if groups are vocal and attract wider attention. Contestation and opposition can be overcome through several processes. First, social or technical adjustments can 


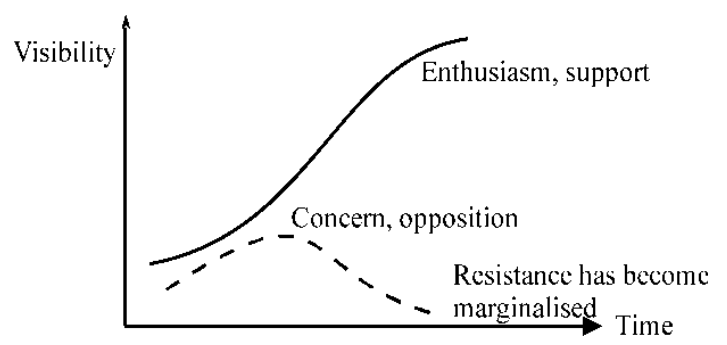

Figure 5. Contested development

be made to alleviate negative effects or compensate disadvantaged groups. Protests against early cars were accommodated through institutional embedding: public authorities created car registration, car tags, driver's license, driving schools, speed limits and traffic police. Second, people may buy the new technology, despite protests and warnings. Expanding markets may overwhelm protest or the opposing network may fragment as members switch camps. By 1905, for instance, wealthy farmers began to buy cars to bring produce to market, thus reducing the strength of protests. Third, promoters and opponents may fight the matter out, engaging in power struggles in the media, court or political lobbying. ${ }^{24}$ Fourth, the variety of conflicting views and meanings is gradually replaced by an emerging consensus about the pros and cons of new technologies. As more people adopt the new technology, interactions and learning processes may lead to closure of the controversy. ${ }^{25}$ This pattern, in which resistance is eventually overcome, is schematically represented in Figure 5.

\subsection{Societal Controversy and Stalemate}

In this pattern, the public does not go along with the promises formulated by product champions and technology developers. While promoters emphasize possible benefits, opponents and the wider public are concerned about possible risks, dangers and moral consequences. Such societal controversies may slow down technological development or lead to stalemates. Some examples are nuclear energy, genetically modified food in Europe, and cloning. ${ }^{26}$ Societal controversies do not suddenly appear, but emerge as conflicts between proponents and opponents escalate. The difference with the previous pattern (contestation) is that concerns and protests are not overcome, but expand (Figure 6). This depends on the attitudes of the actors involved, their interactions and mobilization

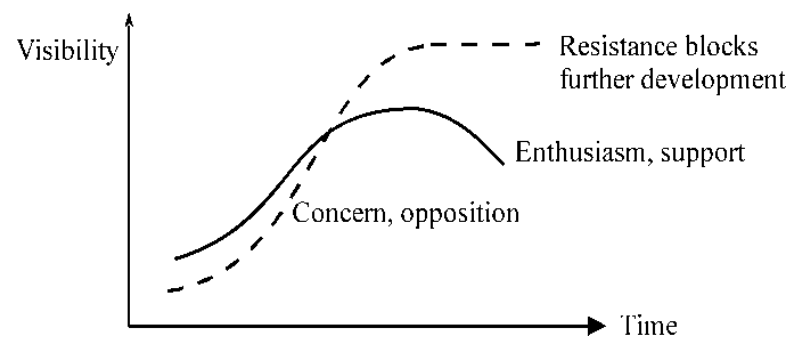

Figure 6. Controversy and stalemate 
strategies. With nuclear energy and GM-food, proponents pushed ahead despite protest, assuming that 'the public' would, in time, become educated and that protests would disappear. This technology-push strategy, backed up by massive R\&D networks, backfired and increased protests. Proponents of nano-technology now try to learn lessons, engage in early stakeholder consultation and dedicate part of their R\&D budgets for constructive technology assessment activities.

\subsection{Waves of Enthusiasm and Concern}

The discussion so far has brought together three relatively familiar patterns of societal embedding, articulating the underlying logic in terms of enthusiasm and resistance. The last two patterns, however, assumed that concern and protest were more or less immediately present. A special pattern of societal embedding may exist in the case of unexpected, negative side effects, which become visible after a certain period of time. In this pattern waves of concern and protest alternate with waves of enthusiasm, market penetration and the establishment of a new industry. This established regime with vested interests defends itself against criticism. Regime insiders may deny the existence of negative side effects or downplay their importance. Once protests accumulate and undermine the product's legitimacy, regime actors may investigate the problem and suggest adjustments in the product. These products may be accepted by the public and lead to renewed enthusiasm. Alternatively, the public may lose faith, leading to the product's demise. This coming and going of waves of enthusiasm and concern can extend over a prolonged period of time. Hence, we hypothesize that the occurrence of side effects leads to a different pattern of societal embedding. This pattern is to be expected for technologies that are used in complex systems, of which causal mechanisms are not fully understood, e.g. natural eco-systems, human body and mind. This hypothesis is further explored with a case study on a particular form of medical technology: psychotropic drugs.

\section{Case Study: Cultural Enthusiasm and Resistance Regarding Psychotropic Drugs}

Therapeutic drugs show in their conception, production, marketing and uses that they are more than just technical commodities. They also reflect developments and transformations in the science and art of healing as a cultural process. However scientific and modern in nature, medicine and its therapies are bound up with dynamic mixtures of opinions, practices and rituals that shape the landscape of health care. Given increasing visibility by marketing practices of industry and used in contexts that have grown more and more subjected to media attention, therapeutic drugs have become in the 19th and 20th century important focal points of cultural mediation and imagination in public domains. These sociocultural dynamics around pharmaceuticals have not only been paramount in defining public images and policies, they have also influenced the production of medical technology as much as the reverse.

The anxiety and sleeplessness of modern life created a growing demand for potions, pills and other psychotropic remedies that promised alleviation or healing. In the late 19th century an emerging pharmaceutical industry that mass-produced drugs with the use of new chemical knowledge, began to compete with pharmacies and quack doctors that produced tailored recipes. Researchers combined chemical substances and tested them for biological and psychological effects. Although tests showed certain correlations 
between drugs and psychological and behavioural changes, there was little understanding of the causal mechanisms in body and mind, but this did not (and does not) prevent scientists from claiming the greatest benefits of their apparent success in unravelling biological mechanisms. As with other medicines, the societal introduction of psychotropic drugs went hand in hand with the observation of unexpected side effects. Depending on the risk calculation and perception involved, this affected or even undermined legitimacy.

The case study explores in a comparative perspective the process of societal embedding of two particular groups of psychotropic agents (barbiturates and benzodiazepines), focusing in particular on cultural enthusiasm, resistance and regulations. The case study gives somewhat less attention to the pharmaceutical business environment, because this aspect of societal embedding has been addressed frequently in innovation studies. ${ }^{27}$ The case study is based on primary and secondary sources from five different countries: Britain, Canada, the USA, Germany and the Netherlands.

\subsection{Barbiturates (1903-1930): Enthusiasm and Some Internal Criticisms}

The chemical compound barbital (diethylbarbituric acid) was developed by the German pharmacologist Joseph von Mering and the chemist Emil Fischer. In 1902 they regarded the chemical compound as interesting because of its potential hypnotic and sedative properties. After demonstrating hypnotic effects without unpleasant side effects in dogs, they proceeded with experimental clinical tests on psychiatric patients. ${ }^{28}$ Fischer and Mering came to an agreement with the German pharmaceutical company E. Merck (Darmstadt) to produce and market the new therapeutic drug. In 1903, when Fischer and Mering published their research findings on 'a new class of hypnotics', they could already refer to the commercial introduction of barbital under the trade name Veronal. Merck's German competitor F. Bayer \& Company rapidly broke the patent position and enforced a shared Veronal patent agreement. ${ }^{29}$

In subsequent years, several clinical psychiatrists wrote enthusiastic publications about Veronal, praising the drug's properties: the almost certain effect of 'natural sleep'; its relative gentle taste (compared to previously existing drugs based on chloral and bromides); and the wide range of indications for which it seemed useful, ranging from depression, neurasthenia and insomnia to anxiety, epilepsy and chronic alcoholism. Only with dementia praecox (schizophrenia) did the effects of the drug seem unreliable. ${ }^{30}$

In the late 19th and early 20th century, pharmaceutical companies struggled to gain credibility and public respectability. ${ }^{31}$ In this context, Veronal had to compete with many other drugs and potions, many of which were ready-made patent medicines. To differentiate Veronal, Merck and Bayer tried to create a medico-scientific image of high trustworthiness, arguing that the drug was scientifically tested. They created scientific information departments to promote new drugs directly to doctors and pharmacists, through the publication of articles and leaflets, through advertisements and through distribution of free samples of the drug. ${ }^{32}$

The new sleeping drug was relatively expensive compared with other hypnotics: four times the price of chloral and 2.7 times the price of paraldehyde. ${ }^{33}$ Nevertheless, Merck noted that the drug 'conquered the world by storm'. It was popular among upper and middle classes, ${ }^{34}$ and was often referred to as the 'fashionable sleeping drug'. ${ }^{35}$ During the first half of the twentieth century, Veronal and other designed barbiturates became the most popular hypnotics and sedatives. Veronal, Verpnal, Medinal (barbital), Luminal (phenobarbital) and later Seconal (secobarbital) and Amytal (amobarbital) became household words. 
Barbital was received enthusiastically by the medical profession and consumers for several reasons. First, the pharmaceutical industry hyped the drug through extensive media campaigns, projecting a scientific image. Second, the growing standard of living of the middle-classes stimulated market demand. Third, demand was stimulated by the health insurance industry with its reimbursement of prescription drugs. Fourth, opiates and the patent medicines associated with them, fell into disrepute. ${ }^{36}$ Their use was formally restricted after the International Opium Convention at The Hague (1912) and the passing of the Harrison Act in the USA (1915). Doctors and lay consumers in search for psychoactive substances with sedative and hypnotic properties increasingly drifted towards the barbiturates. Fifth, barbiturates linked up with the deep cultural belief in 'wonder drugs'. ${ }^{37}$ While the curative power of many medicines was still limited, this generic belief helped to give the pharmaceutical industry legitimacy. The belief in wonder drugs was part of a compensatory mechanism to help consumers cope with the yawning gap between the promises and expectations of scientific medicine and every day experiences of incurable disease and failing remedies. To legitimate this belief, there was great willingness to give drugs such as barbital the status of wonder drug, thus contributing to its popularity.

Within expert communities, however, doubts emerged about medical and social side effects, including addiction problems and 'inappropriate' use. The first German and English publications on side effects appeared in 1903 and $1904 .{ }^{38}$ Subsequent studies noted problems of addiction and physical dependence, tiredness during the day, hangovers, dizziness, unsteady gait, slurred speech, allergic reactions and epileptic seizures as well as suicidal tendencies and chronic barbiturate intoxication. ${ }^{39}$ In addition, the fatal outcome of 'Veronal taking' in very large doses was reported within the first decade of its introduction. In response the German manufacturers Bayer and Merck began to caution against 'inappropriate use', i.e. exceeding therapeutic doses, but these critical discussions occurred mainly in closed, specialist communities. It was not until the 1920s that some critical appraisal of Veronal and other barbiturates emerged in the public sphere. In her popular 1922 book The Black Candle against drug abuse, the Canadian judge Emily Murphy gave an early warning against barbiturate use in terms of 'anything that acts like an opiate $I S$ an opiate'. ${ }^{40}$ In subsequent years, alarming media reports began to appear with statistics of accidental and intentional barbiturate deaths among the middle classes. Ultimately, the combination of spectacular reports on single cases of sleeping draught abuse with (near) fatal accidents among the rich and famous (e.g. Marcel Proust, Virginia Woolf and the German actor Max Linder) put barbiturate use on the political and legislative agenda in Western countries. ${ }^{41}$

From 1926 onwards the supply of barbiturates was increasingly restricted under different national drug acts, with Britain and Germany taking the lead. ${ }^{42}$ In both countries Veronal and subsequently Luminal became prescription-only drugs, which officially could be dispensed only by licensed pharmacists and chemists.

\subsection{Second-Generation Barbiturates (1930-1960): Renewed Enthusiasm, Followed by Criticism}

Despite restrictive policies and warnings in the media, public demand for modern sleeping drugs kept growing, but public concern undermined the legitimacy of barbiturates. Hence, German, British and American pharmaceutical companies adjusted their products, 
developing more potent, short-acting and presumably safe barbiturate analogues like cyclobarbital (Phanodorm), amobarbital (Amital), pentobarbital sodium (Nembutal) and thiopental sodium (Pentothal). ${ }^{43}$ These drugs were rhetorically called 'second-generation' barbiturates to distinguish them from the 'classic' barbiturate Veronal, which fell into relative disrepute.

This strategy allowed proponents of the barbiturates to defend themselves against criticism. In Britain this was exemplified by the controversy between the 'detective-physician' Sir William Wilcox, who argued that the barbiturates occupied the foremost place among the drugs of addiction and suicide, and the psychiatrist R.D. Gillespie, who maintained that there was no conclusive evidence of a higher risk, especially for the improved second generation drugs. ${ }^{44}$ Such professional debates hardly affected public demand for barbiturates. For the second-generation barbiturates, prescription and consumption kept growing exponentially. Doctors were persuaded by the pharmaceutical industry that there was much difference between first and second-generation drugs in terms of potency, margin of safety, duration of action and therapeutic indications. ${ }^{45}$ By 1950 more than 50 types of barbiturates were on the market and about a dozen were in common use. ${ }^{46}$

Although barbiturates were lavishly supplied on medical prescription, there was also a substantial illicit market. The American Food and Drug Administration (FDA) took the lead by placing all barbiturates on the list of dangerous prescription-only drugs in. It associated abuse among youths and young with an alarming increase in traffic accidents. In 1939 Newsweek warned for the 'lullaby pill peril'. ${ }^{47}$

The Second World War, however, triggered a further increase in the demand for barbiturates, often combined with amphetamines. ${ }^{48}$ Servicemen returning home with barbiturate and amphetamine experiences and supplies found receptive ground among the anxious and traumatized population of the Western countries. US production capacity almost doubled between 1941 and 1947, from 198,000 kg to 336,000 kg of barbiturates. ${ }^{49}$ In 1948 drug companies produced 24 pills for every American citizen. This amount was claimed to be far beyond 'legitimate medical needs' and to be comparable to that of the opiates at the turn of the 19th century. ${ }^{50}$ The post-war period of reconstruction and cold-war related stress helped to keep demand high. The prescription-only rules were widely circumvented, and many pills disappeared in the illegal market. An American estimate was that half of the production was meant for the illicit market with its distribution channels through saloons, taxi drivers and truck stops. ${ }^{51}$

In the 1950 s, up to $15 \%$ of all medical prescriptions in Canada, Britain, Germany, the Netherlands and the USA were estimated to be barbiturates. ${ }^{52}$ Ongoing research in the pharmaceutical industry led to a rapid expansion of knowledge, products and medicines in the post-war period. The pharmaceutical industry overwhelmed doctors with information leaflets, informing them about their expanding armoury of hypnotics, sedatives, tonics, stimulants and salts for the treatment of overstrained nerves. ${ }^{53}$ There still was general optimism about medical-scientific curative powers. Advertisements positioned the new drugs as answers to the accelerating pace of modern life that harmed the nerves of businessmen, schoolteachers and housewives. In consulting rooms, consumers sought pharmaceutical means to sooth the stress and anxieties of every day live. Doctors prescribed barbiturates promiscuously and pharmacists did not assume any obligation for responsible refills. In 1955 the Daily Mirror reported that barbiturates for the British were 'as much a part of the daily routine for thousands as cleaning their teeth'. ${ }^{54}$ Some critics argued that doctors prescribed the drugs too easily to meet the 
expectations' trap of modern medicine, i.e. to fulfil the curative promises of modern medicine. ${ }^{55}$ The critics lamented this practice, because barbiturates were thought to be associated with deadly accidents and suicides, but critical debates about prescribed barbiturates were restricted to small circles and did not lead to widespread societal concern in the 1950s.

In the 1960s, however, concern arose about the combined use of barbiturates with diet pills and other amphetamine products (like benzedrine inhalers). This combination of 'uppers' and 'downers' had synergistic effects, making users feel more euphoric and relaxed than if they had taken either drug by itself. ${ }^{56}$ This combined use became popular among fast growing middle class youth drug subcultures such as the British 'mods'. The drugs acquired street names like 'goof balls/G.B.s', 'dolls', 'King Kong pills', 'peanuts', 'red devils' (Seconal) or 'blue angels' (Amytal). ${ }^{57}$ The enchanted terms 'Christmas trees', 'purple hearts' and 'French blues' referred to the popular combination of dexamphetamine (upper) and amylobarbital (downer). ${ }^{58}$ Abuse and fatal accidents among the rich and famous (Marilyn Monroe in 1962, Judy Garland in 1969), published in spectacular media reports, drew attention to this combined practice and placed barbiturate use back on the political and legislative agenda. ${ }^{59}$ Health policy makers, such as the FDA, the FBI, the Canadian, German and Dutch Ministries of Health and Welfare, the British Department of Health and Social Security, and the WHO Expert Committee on Drug Dependence were concerned about the perceived epidemic of self-administration of psychotropic drugs, in particular amphetamines and barbiturates. ${ }^{60}$ While medical opinion in the 1950s was still divided about the addictive, habit-forming and abuse potentialities of barbiturates, consensus on these topics emerged in the mid-1960s. This tarnished the medical reputation of the barbiturates more profoundly. There was reason for concern because, according to 1966 FDA estimates, there were about 500,000 barbiturate abusers in the USA. ${ }^{61}$ In Britain it was estimated that approximately 110,000 cases of barbiturate poisoning occurred in $1959,{ }^{62}$ but the general consensus about abuse potential of barbiturates did not lead to strict regulations. Only in the USA, recommendations were effectuated to place the production, distribution and use of barbiturates under stricter than 'prescription control'. ${ }^{63}$

\subsection{Benzodiazepines (1960-1970): Renewed Enthusiasm}

In 1955 the chemist Leo Sternbach (1908-2005) synthesized the benzodiazepine compound chlordiazepoxyde, which formed the basis for a new generation of drugs: benzodiazepines. Under the trade name Librium, the pharmaceutical company Hoffmann-La Roche launched this drug in 1960 as medication for anxieties and tensions. ${ }^{64}$ Librium was the first representative of a new chemical family: the benzodiazepines or 'benzos'. Product champions promised that Librium helped against anxieties without the problems of dependence and overdosing associated with the barbiturates. In terms of marketing, Librium could fill the gap between traditional sedatives and hypnotics (such as barbiturates) and newly developed antipsychotic and antidepressant medicines. As such, Librium was positioned in the new therapeutic class of 'minor tranquillizers'. This differentiated it from 'major tranquillizers' (such as Thorazine and Miltown), which were first used for the doctoring of madness (anti-psychotic). In the late 1950s some of the major tranquillizers became bestsellers as popular 'happiness pill' in Britain, Canada and the USA, showing the market potential of the tranquillizer concept. ${ }^{65}$ As 'minor tranquillizer', 
Librium hoped to tap into this potential and open up the mass treatment of nervous problems in 'the age of anxiety'.

The extensive worldwide information campaign of Roche, directed at specialists and general practitioners, and the inflationary spiral of stories in the media about a new medicinal drug with miraculous calming effects in small doses and no manifest side effects, turned Librium into an overnight sensation. Expectations were high, as indicated by the following phrase in Life Magazine in 1960: 'The drug that tames wild cats: What will it do for nervous women?' ${ }^{66}$ Librium was world news and Roche set a new global marketing standard for blockbuster drugs. They adopted a single brand name and offered an embracing treatment concept. This package consisted of a practical system of symptom identification, diagnostics, mode of action and therapy. They also offered a mode of understanding, conceptualizing treatment as chemically restoring the balance between body and mind. The so-called 'limbic system' was presented as specific switcher mechanism and Librium as instant limbic stabilizer 'whatever the diagnosis' ${ }^{67}$ This new chemotherapeutic approach of nervous problems prepared the way for introducing supplementary tranquillizers with different therapeutic profiles. In 1963 Roche introduced the more potent and anxiety-specific benzodiazepine analogue diazepam under the trade name Valium. ${ }^{68}$ Marketed as the most potent and safe 'anxiolytic' Valium rapidly surpassed Librium as the best selling tranquillizer in Western countries, giving rise to the Valium frenzy or 'Valiumania'. 99 In 1965 Roche introduced another benzo, the sleeping-pill Mogadon (nitrazepam). ${ }^{70}$ This drug was claimed to be reliable and safe and did not, in contrast to the 'traditional hypnotics' (i.e. the barbiturates), lead to narcosis, coma, or death in case of an overdose. ${ }^{71}$ Sleeplessness, nervousness, overexertion, stomach and back pains, hypertension and heart problems, and psychotic disorders (schizophrenia, manic depression) became indications for the administration of members of the expanding 'benzo-family'. The 'wonder drugs' were prescribed and used as answer to everything, including the 'normal' emotional reactions to life's everyday challenges. ${ }^{72}$ German physicians came to use the following aphorism: 'Wenn man nicht weiss, wie, was, warum, dann gibt man immer Valium' (when you don't know how, what and why, then it is time for Valium). ${ }^{73}$ Such popular representations mirrored consumption statistics. From the early 1960s up to late 1970s Librium, Valium, Mogadon and other benzos led the drug list in Western countries. ${ }^{74}$

The rapid rise of the benzos did not lead to the complete disappearance of the barbiturates. Some barbiturates continued to be used for specific official therapeutic applications, e.g. anaesthetics, forensic medicine, narco-analysis, epileptics' treatment and euthanasia medication (Pentothal injection), but there was also ongoing illicit non-medical use, as a result of which barbiturates continued to resurface in the public domain as dangerous narcotics, especially in the USA. Nevertheless, barbiturates were no longer the focus of intense symbolic activity in the 1960s.

\subsection{Societal Concern and Second-generation Benzos (1965-2000)}

The initial enthusiasm and optimistic promises regarding benzos were increasingly questioned by professionals and the public. Within the medical community, side effects of benzos were reported as early as 1961 by the American medical internist Leo Hollister: tolerance, dependence, drowsiness, reduced alertness and other reactions leading to traffic accidents. ${ }^{75}$ Not only physical, but also cultural and social side effects appeared 
in societal debates, as counterculture movements took a critical look at society. In 1966, psychologist Leslie Farber wrote a critical essay 'ours is the addicted society', warning against the tremendous expansion of psychotropic drugs. In the same year, Dutch psychiatrist Herman van Praag wrote a book for medical practitioners, arguing that the therapeutic areas for which benzos were applied, multiplied unchecked. ${ }^{76}$ The expanding use of tranquillizers seemed a hypocritical way to deal with the expectations of 'The Good Life' and the social anxieties and tensions this apparently generated. ${ }^{77}$ Criticisms of benzos were partly also criticisms of society. The Rolling Stones' hit 'Mother's Little Helper' (1966) epitomized the critique of middle-class tranquillizer addiction, alienation and hypocrisy.

This period saw an intensive and visible public controversy. On the one hand, there was mounting medical and social concern over negative side effects. On the other hand, the expanding arsenal of psychotropic drugs and the medico-scientific claims of a controllable brain chemistry appealed to the public imagination. Despite public debates and concerns over addictive and potentially harmful consequences, public demand for benzodiazepines continued to grow. ${ }^{78}$ Medical consumers became more vocal and increasingly regarded stress- and anxiety-related problems in daily life as inconvenient and undesirable. They sought treatment, inspired by the promise of psychoactive magic bullets, with specific effects on brain chemistry.

Drug firms, scientists, doctors, pharmacists and chemists wanted to meet this demand for psychotropic treatments, but the public debates threatened the legitimacy of benzos. Hence, in the 1970s and 1980s, American and Swiss pharmaceutical companies introduced a second-generation of short-acting and presumably safe benzo analogues like Halcion (triazolam) and Dormicum (midazolam). ${ }^{79}$ The 'classic' benzos Librium and Mogadon gradually fell into relative disrepute and their use gradually diminished. The second-generation benzos were promoted as non-addictive alternatives to the firstgeneration of benzos. Halcion, for instance, was hailed by US doctors and consumers as the new safe and sane sleeping pill. It remained a blockbuster drug on the US market until the early 1990s. ${ }^{80}$ In the Netherlands, however, Halcion faced more criticism and was associated with negative side effects such as amnesia, hallucinations, aggression and homicide. The Dutch anti-psychiatry movement criticized Halcion as a 'therapeutic nightmare', creating a public controversy that killed its market prospects. ${ }^{81}$

Although the second-generation benzos experienced market success in some countries, the late 1970s and early 1980s saw a surge of public criticism, which eroded its legitimacy. Consumers, health professionals, politicians and government agencies in all countries under survey expressed concern with tranquillizers and benzodiazepines. ${ }^{82}$ Critics within the medical profession increasingly spoke publicly about their concerns. In Canada the government held parliamentary debates that led to benzodiazepines being placed on Canada's list of controlled substances. The World Health Organization followed suit. ${ }^{83}$ In the media, benzos were 'hot' as fashionable bad news stories. The concern over benzos was related to broader cultural changes such as reduced faith in scientific and medical expertise, and lawsuits by disadvantaged patients, backed up by lawyers. ${ }^{84}$

In the 1990s, the rise to stardom of the antidepressant Prozac and its clones as the new psychoactive wonder drug silenced the benzodiazepine debate. Professional and public discussions shifted from the 'outdated' benzos to a new chemical family of psychotropic pills (SSRI, selective serotonin reuptake inhibitors), but below the surface of public debate, benzos and tranquillizers continued to be used. Between 1983 and 1992, the use 
of benzos in the Netherlands decreased from $12 \%$ to $10 \%$ of the population, but since 1993 benzos' market share grew again, despite the explosive growth of antidepressant consumption (Prozac). ${ }^{85}$ Long-term repeat prescriptions, especially among elderly women, increased from $1.9 \%$ of the Dutch population in 1982 to $3 \%$ in $1994 .{ }^{86}$ However hidden, the problem of 'addiction by prescription' entered the public agenda because of self-organization by patient groups. To fight the tranquillizer trap, Joan Gadsby, a Canadian advocate, set up the Benzodiazepine Call to Action Group in 1995. This new form of collective consumer action was imitated by similar initiatives in other countries, e.g. the Victims of Tranquillizers (VOT) group in Britain, the Tranquillizer Users' Recovery Network in the USA, and most recently the international Benzodiazepine Awareness Network (BAN). ${ }^{87}$ These groups struggled for recognition of the permanent negative consequences they suffered as a result of (prolonged) use of benzos. They also took on the role of monitoring research and policy issues, circulating their information and opinions among a wider public. Through magazines, newsletters, meetings and Internet websites they aimed to promote individual vigilance of consumers and to maintain a permanent collective awareness of the 'hidden epidemic' ${ }^{88}$ This recent development towards consumer-led platforms for the appraisal of pharmaceutical information seems part of a broader process of reordering private and public responsibilities in the medical sector.

\section{Analysis}

The case study shows that the societal embedding of psychotropic drugs was more complex than the three patterns, described in Section 2. In Section 1 we distinguished three relevant environments (business environment, regulation environment, wider society), and argued that societal embedding involves stable alignment between them. The longitudinal case study shows that the societal embedding of psychotropic drugs proceeded well in the business environment. Despite warnings and reports of negative side effects, commercial demand for these drugs grew substantially throughout the 20th century. Apparently, the quest for solutions to problems of stress, anxiety and nervousness was bigger than the fear for possible side effects. Despite market success, however, societal embedding did not achieve permanent stability. Tensions and de-alignment occurred several times in the public sphere, followed by regulatory changes. Unexpected side effects, whether technical or social in nature, were the major factor in undermining the legitimacy of psychotropic drugs, giving rise to resistance. This confirms our hypothesis that the occurrence of negative side effects gives rise to special patterns of societal embedding. In the case study, societal embedding was an ongoing process of waves of enthusiasm and concern, which required a lot of repair work with regard to legitimacy and public acceptance.

Overall dynamics consisted of combinations of the three patterns, described in Section 2, with periods of high enthusiasm being alternated by periods of bigger or smaller concerns and opposition. More precisely, enthusiasm and resistance did not really alternate, but coexisted and were carried by different groups. Enthusiasm was more or less present all the time, carried by customers and pharmaceutical product champions. Concern often simmered within expert communities, and sometimes spilled over into the media and public debates. Figure 7 gives a schematic, qualitative impression.

The societal embedding of new psychotropic drugs usually began with optimistic promises and enthusiasm about 'wonder drugs', following the first pattern (hype-cycle). Critical 


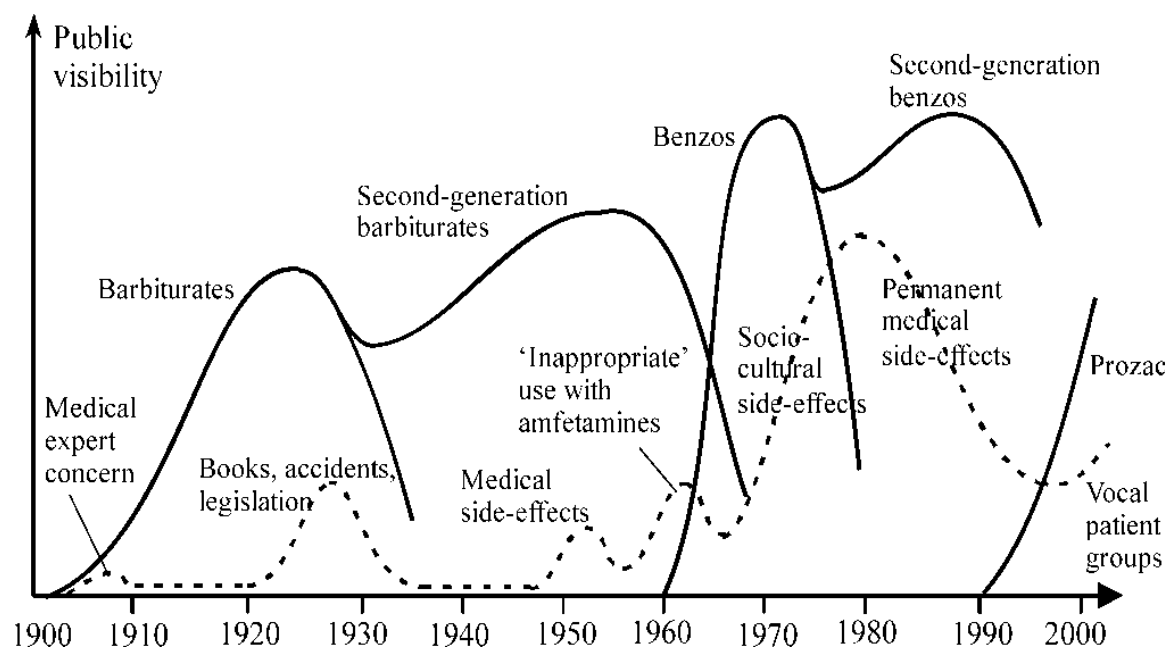

Figure 7. Waves of enthusiasm and concern (dotted line) regarding psychotropic drugs

voices within expert communities were kept indoors. Eventually reports about negative side effects accumulated, leading to increased societal concern, often galvanized by spectacular accidents by the rich and famous. In the first half of the 20th century, negative reports and resistance remained moderate, as in the second pattern (contestation). In the second half of the 20th century, resistance became more vocal, received more public attention and led to a controversy in the late 1960s and 1970s. But contestation and controversy did not lead to stalemates (as in the third pattern). One reason was that commercial demand remained strong. Another reason was repair work by the pharmaceutical industry, particularly through adjusting the drugs. In two instances, this led to so-called second-generation drugs. Each gave rise to new hypes and promises of products without side effects. The surprising thing is that the public usually accepted these promises, despite the industry's bad track record in keeping them. The marketing practices of pharmaceutical companies certainly played a role here, and the various ways through which they influenced medical doctors. Waves of enthusiasm and disappointment repeated themselves in the case study, suggesting limited awareness in society of earlier experiences. However, some changes did occur in the medical regime in the last three decades, partly inspired by previous experiences. Medical Technology Assessment committees have been created, and ministerial health inspectors have become more critical of the industry's reporting on test results of new drugs. Scandals in the last five years with drugs such as Seroxat/ Paxil (a Prozac-like antidepressant) or Vioxx (a specific analgesic) may suggest a lax application of drugs admission rules, but they can also be interpreted as increased recognition of the uncertainties with new drugs and an unwillingness to take the industry's promises at face value. Active patient groups and consumer-led platforms have been important in this respect, suggesting some institutionalization of critical and reflexive viewpoints. These changes have not yet, however, affected the general pattern of waves of enthusiasm and concern.

With regard to enthusiasm and concern, we should also note the influence of the broader social, cultural and political environment. The barbiturates' enthusiasm of the early 
20th century was influenced by the broader struggle of professional medicine to achieve societal recognition. Hence, the drive to create a scientific image around Veronal and the willingness to support the belief that science could deliver 'wonder drugs'. Also the expansion of insurance schemes boosted scientific medicine. In the post-war reconstruction period, general faith in science was also high. This benefited secondgeneration barbiturates and benzos, and stimulated the acceptance of an image such as 'chemically restoring the balance between body and mind'. In the 1960s and 1970s criticisms of psychotropic drugs were enhanced by being taken up by the broader counterculture movements. Criticism in the 1970 s could build on the lost faith in scientific progress and images of technology-out-of-control. This was followed in the late 1980s by a wave of bio-optimism that coincided with the launch of a new generation of antidepressants. So, the steepness of waves of enthusiasm and resistance depend partly on linkages with wider societal developments.

\section{Conclusions}

The societal embedding of new technologies involves market dynamics, regulation and public acceptance. These aspects are often fragmented among different research traditions. This article has tried to bring cultural aspects explicitly into innovation studies. This was done by conceptualizing interactions between product champions, cultural enthusiasm, concern and resistance. The research question was: how do these interactions result in different trajectories of societal embedding of new technologies? To answer this question, the article made two contributions. First, it articulated the logic that underlies three familiar patterns of societal embedding: (i) hype-cycle, (ii) contested embedding, and (iii) controversy and stalemate. Second, we distinguished a fourth additional pattern for technologies that have unexpected side-effects. This pattern consists of combinations of the other three patterns, starting usually with optimistic promises and hype-cycles, but turning into one of the other two patterns as negative side effects appear. Dynamics are even more complex when the established industry engages in repair work and advances improved products, which may start a new hype-cycle. The strength of protests and linkages with the broader environment determine forms and contents of waves of enthusiasm and resistance. The case study of psychotropic drugs demonstrated how such dynamics can unfold. Hence, we conclude that at least four characteristic patterns exist in societal embedding of new (medical) technologies. We also conclude that the incorporation of cultural dynamics in innovation studies is worthwhile and useful as a complement to the strong focus on business environments and firm-based processes.

\section{Acknowledgements}

We want to thank two anonymous referees for their useful comments on a previous version of this paper. We also gratefully acknowledge financial support from the Dutch Knowledge network on System Innovation (KSI).

\section{Notes and References}

1. J. J. Deuten, A. Rip \& J. Jelsma, Societal embedding and product creation management, Technology Analysis \& Strategic Management, 9(2), 1997, pp. 131-148.

2. J. J. Corn, The Winged Gospel: America's Romance with Aviation, 1900-1950 (New York: Oxford University Press, 1983); P. Du Gay, S. Hall, L. Janes, H. MacKay \& K. Negus, Doing Cultural 
Studies: The Story of the Sony Walkman (London: Sage Publications, 1997); J. Van Dijck, Imagenation: Popular Images of Genetics (New York: New York University Press, 1998); T. Pieters, Interferon: The Science and Selling of a Miracle Drug (London, Routledge, 2005).

3. A. Jamison \& M. Hård, The storylines of technological change: innovation, construction and appropriation, Technology Analysis \& Strategic Management, 15(1), 2003, pp. 81-91.

4. R. Kemp, J. Schot \& R. Hoogma, Regime shifts to sustainability through processes of niche formation: the approach of strategic niche management, Technology Analysis \& Strategic Management, 10, 1998, pp. $175-196$.

5. F. W. Geels, The dynamics of transitions in socio-technical systems: a multi-level analysis of the transition pathway from horse-drawn carriages to automobiles (1860-1930), Technology Analysis \& Strategic Management, 17(4), 2005, pp. 445-476.

6. D. Nye, Electrifying America: Social Meanings of a New Technology (Cambridge, MA: The MIT Press, 1990).

7. S. S. Blume, Insight and Industry: On the Dynamics of Technological Change (Cambridge, MA: MIT Press, 1992); B. Holtzmann Kevels, Naked to the Bone: Medical Imaging in the Twentieth Century (New Brunswick, NJ: Rutgers University Press, 1997).

8. R. Coombs, K. Green, A. Richards \& V. Walsh (Eds), Technology and the Market: Demand, Users and Innovation (Cheltenham, UK: Edward Elgar, 2001); N. Oudshoorn, and T. Pinch (Eds), How Users Matter: The Co-Construction of Users and Technology (Cambridge, MA: The MIT Press, 2003).

9. H. Van Lente, Promising Technology: The Dynamics of Expectations in Technological Development (Delft: Eburon, 1993); M. Bauer, Resistance to New Technology (Cambridge: Cambridge University Press, 1995); H. Van Lente and A. Rip, Expectations in technological developments: an example of prospective structures to be filled in by agency, in: C. Disco \& B. J. R. van der Meulen (Eds), Getting New Technologies Together (Berlin: Walter de Gruyter, 1998), pp. 195-220.

10. C. Perez, Technological Revolutions and Financial Capital: The Dynamics of Bubbles and Golden Ages (Cheltenham: Edward Elgar, 2002).

11. N. Brown, Organising/disorganising the breakthrough motif: Dolly the cloned ewe meets Astrid the hybrid pig, in: N. Brown, B. Rappert \& A. Webster (Eds), Contested Futures: A Sociology of Prospective Technoscience (Aldershot: Ashgate, 2000), pp. 87-108.

12. M. Hård \& A. Jamison, Hubris and Hybrids: A Cultural History of Technology and Science (London: Routledge, 2003); T. P. Hughes, The Human-Built World: How to Think About Technology and Culture (Chicago: The University of Chicago Press, 2004).

13. J. Turney, Frankenstein's Footsteps; Science, Genetics and Popular Culture (New Haven, CT: Yale University Press, 1998).

14. A. Rip \& S. Talma, Antagonistic patterns and new technologies, in: C. Disco \& B. J. R. van der Meulen (Eds), Getting New Technologies Together (Berlin: Walter de Gruyter, 1998), pp. 299-322.

15. A. Rip, T. Misa \& J. Schot (Eds), Managing Technology in Society: The Approach of Constructive Technology Assessment (London: Pinter, 1995).

16. Corn, op. cit., Ref. 2.

17. B. Hansen, New images of a new medicine: visual evidence for the widespread popularity of therapeutic discoveries in America, Bulletin of the History of Medicine, 73, 1999, pp. 629-678.

18. F. W. Geels \& W. A. Smit, Failed technology futures: pitfalls and lessons from a historical survey, Futures, 32, 2000, pp. 867-885.

19. S. Snelders, C. Kaplan \& T. Pieters, On cannabis, chloral hydrate, and career cycles of psychotrophic drugs in medicine, Bulletin of the History of Medicine, 80, 2006, pp. 95-114.

20. G. Mom, The Electric Vehicle: Technology and Expectations in the Automobile Age (Baltimore, MD: The John Hopkins University Press, 2004).

21. Geels, op. cit., Ref. 5.

22. Mom, op. cit., Ref. 20.

23. W. E. Bijker, Of Bicycles, Bakelites and Bulbs: Towards a Theory of Sociotechnical Change (Cambridge, MA: The MIT Press, 1995).

24. M. Hård, Beyond harmony and consensus: a social conflict approach to technology, Science, Technology \& Human Values, 18(4), 1993, pp. 408-432.

25. Bijker, op. cit., Ref. 23.

26. Brown, op. cit., Ref. 11. 
27. F. M. Santos, The co-evolution of firms and their knowledge environment: insights from the pharmaceutical industry, Technological Forecasting and Social Change, 70, 2003, pp. 687-715; M. McKelvey \& L. Orsenigo, Pharmaceuticals as a sectoral innovation system, in: F. Malerba (Ed.), Sectoral Systems of Innovation (Cambridge: Cambridge University Press, 2004).

28. Barbital was just one among many other psychotropic compounds which were tested in German psychiatric clinics; see, K. Goder, Zur Einführung Synthetischer Schlafmittel in die Medizin (Frankfurt am Main: Peter Lang, 1985).

29. See for detailed accounts on the early development of the barbiturates: M. M. Weber, Die Entwicklung der Psychopharmakologie im Zeitalter der Naturwissenschaftlichen Medizin. Ideeengeschichte eines Psychiatrischen Therapiesystems (München: Urban \& Vogel, 1999); T. J. Rinsema, De Natuur Voorbij. Het Begin van de Productie van Synthetische Geneesmiddelen (Leiden: Meppel, 2000).

30. F. Hall, Psychopharmaka: Ihre Entwicklung und Klinische Erprobung (Hamburg: Verlag Dr Kovac, 1997), pp. 207-210.

31. J. Liebenau, Medical Science and Medical Industry (Baltimore, MD: The Johns Hopkins University Press, 1987).

32. Rinsema, op. cit., Ref. 29, pp. 214-219, 300-303.

33. Weber, op. cit., Ref. 29, p. 95.

34. Weber, op. cit., Ref. 29, p. 108.

35. Hall, op. cit., Ref. 30, p. 210.

36. B. Hodgson, In The Arms of Morpheus: The Tragic History of Laudanum, Morphine, and Patent Medicine (New York: Firefly Books, 2001), pp. 125-128; J. H. Young, The Medical Messiahs (Princeton, NJ: Princeton University Press, 1967), pp. 13-40; R. Davenport-Hines, The Pursuit of Oblivion (New York: W.W. Norton \& Co., 2002), pp. 200-225; D. T. Courtwright, Forces of Habit: Drugs and the Making of the Modern World (Cambridge, MA: Harvard University Press, 2001), p. 105.

37. See for a detailed analysis of the historical process of hailing miracle drugs: Pieters, op. cit., Ref. 2.

38. D. R. Wesson \& D. E. Smith, Barbiturates: Their Use, Misuse and Abuse (New York: Human Sciences Press, 1977), p. 52; Davenport-Hines, op. cit., Ref. 36, p. 245.

39. Weber, op. cit., Ref. 29, p. 109.

40. E. F. Murphy, The Black Candle (Toronto, Thomas Allen, 1992), p. 19.

41. K. Pohlisch \& F. Panse, Schlafmittelmissbrauch (Leipzig, Georg Thieme Verlag, 1934), pp. 1-13; Davenport-Hines, op. cit., Ref. 36, pp. 246-251.

42. Pohlisch \& Panse, op. cit., Ref. 41, pp. 14-16; Davenport-Hines, op. cit., Ref. 36, p. 250; Murphy, op. cit., Ref. 40; A. J. H. Ebes, Experimentele Bijdrage tot de Behandeling van de Acute Slaapmiddelvergiftiging met Doodelijke Dosis (Groningen: Thesis, 1938).

43. Wesson \& Smith, op. cit., Ref. 38, pp. 15-17; Pohlisch \& Panse, op. cit., Ref. 41, pp. 14-16; W. Sneader, Drug Discovery: A History (Chichester: Wiley, 2005).

44. C. Medawar \& A. Hardon, Medicines Out of Control? Antidepressants and the Conspiracy of Goodwill (Amsterdam, Aksant, 2004), p. 23.

45. Medawar \& Hardon, op. cit., Ref. 44, pp. 23-25; D. C. Lai, Pentothal Postcards (New York: Mark Batty, 2005).

46. Wesson \& Smith, op. cit., Ref. 38, p. 20.

47. Ibid., p. 53; Pohlisch \& Panse, op. cit., Ref. 41, pp. 14-16; Davenport-Hines, op. cit., Ref. 36, p. 250.

48. C. O. Jackson, Before the drug culture: barbiturate/amphetamine abuse in American society, Clio Medica, 11, 1976, pp. 47-58.

49. Ibid., p. 50.

50. Young, op. cit., Ref. 36, p. 272; Wesson \& Smith, op. cit., Ref. 38, p. 53.

51. Young, op. cit., Ref. 36, pp. 279-280; Jackson, op. cit., Ref. 48.

52. W. G. Zelvelder \& F. A. Nelemans, Slaap, Slaapstoornissen en Slaapmiddelen (Leiden: Stafleu, 1972).

53. For example, Dutch advertisement folders Coffadyn (d-amphetamine/coffeïne mixture) 1954, Mevec Den Haag, code 585 N; Broomnervaciet (kaliumbromide/barbital mixture) 1955, Mevec Den Haag, code $631 \mathrm{~N}$; Drinamyl (dexedrine + amylobarbital), Smith Kline \& French/Haas Arnhem, codes DL:SC/H46 and F/UK36H, 1956; Ritalin (methylphenidate) 1955, Ciba, Arnhem; D. Healy, The Antidepressant Era (Cambridge, MA: Harvard University Press, 1997), pp. 75-77.

54. Davenport-Hines, op. cit., Ref. 36, p. 315.

55. Jackson, op. cit., Ref. 48, p. 51. 
56. Courtwright, op. cit., Ref. 36, p. 105; L. Grinspoon \& P. Hedblom, The Speed Culture (Cambridge, MA: Harvard University Press, 1975), p. 178.

57. Wesson \& Smith, op. cit., Ref. 38, pp. 121-122; G. Le Dain, I. L. Campbell, H. Lehmann, J. P. Stein, M. Bertrand \& J. J. Moore. The Non-Medical Use of Drugs, Interim report of the Canadian Government Commission of Inquiry (Harmondsworth, UK: Penguin Books, 1971), p. 51.

58. Ibid.

59. M. M. Houle, Tranquillizer, Barbiturate, and Downer Drug Dangers (Berkeley Heights, CA: Enslow, 2000), pp. 5-8, 22-29.

60. Le Dain, op. cit., Ref. 57. UK Department of Health and Social Security (UK DHSS), Amphetamines, barbiturates, LSD and cannabis: their use and misuse. Reports on Public Health and Medical Subjects No. 124, UK DHSS; H. Isbell \& T. L. Chrusciel, Dependence Liability of 'Non-narcotic' Drugs. Bulletin of the World Health Organization, Vol. 43 (Suppl.) (Geneva: WHO, 1971); Zelvelder \& Nelemans, op. cit., Ref. 52, pp. 113-127; B. Pfaeltzer (Ed.), Verslavingsziekten van Farmacologisch, Sociologisch en Psychiatrisch Standpunt Bezien (De Bilt, AGOV, 1959).

61. Isbell \& Chrusciel, op. cit., Ref. 60, p. 24.

62. UK DHSS, op. cit., Ref. 60, p. 18.

63. D. C. Lewis, Alcohol, Barbiturates, Tranquillizers: The drug Experience: Data for Decision-Making (Boston, MA: CSCS, 1970), p. 47.

64. A. Baenninger, J. A. Costa e Silva, I. Hindmarch, H. Moeller \& K. Rickels, Good Chemistry: The Life and Legacy of Valium Inventor Leo Sternbach (New York: McGraw Hill, 2004), pp. $65-75$.

65. E. Shorter, A History of Psychiatry: From the Era of the Asylum to the Age of Prozac (New York: John Wiley, 1997), pp. 314-316; Healy, op. cit., Ref. 53.

66. Baenninger et al., op cit., Ref. 64, p. 74; A. Tone, Listening to the past: history, psychiatry and anxiety, Canadian Journal of Psychiatry, 50, 2005, pp. 373-380.

67. T. Pieters \& S. Snelders, Antidepressiva van 1950 tot heden; een halve eeuw op chemische wolken (Antidepressants from 1950 to the present: a half century of drifting on chemical clouds), Maandblad Geestelijke Volksgezondheid, 60, 2005, pp. 207-222.

68. Baenninger et al., op. cit., Ref. 64, p. 103.

69. Shorter, op. cit., Ref. 65, p. 319.

70. L. H. Sternbach, The benzodiazepine story, in: R. G. Priest, U. Viuanna Filho, R. Amrein \& M. Skreta (Eds), Benzodiazepines Today and Tomorrow (Trowbridge, UK: Redwood Burn, 1980), pp. $5-19,15$.

71. Advertisements for Mogadon in 1967 in the Nederlands Tijdschrift voor Geneeskunde and in Huisarts en Wetenschap. F. Hoffmann-La Roche, Mogadon reclame, code 67573.

72. Tone, op. cit., Ref. 66, p. 378.

73. H. G. Rooymans \& F. G. Zitman, Benzodiazepinen (Alphen aan de Rijn, Stafleu, 1982), p. 7.

74. Baenninger et al., op. cit., Ref. 64, pp. 65-66, 103-104.

75. A. G. Th. van der Lugt, Nadelen van Librium (Disadvantages of Librium), Nederlands Tijdschrift voor Geneeskunde 105, 1961, p. 992; A. G. Th. van der Lugt, Use and abuse of tranquillizers and some other psychotropic drugs: a discussion, Medical Science, 38, 1967; F. A. Nelemans, Psychofarmaca in het verkeer (Psychotropic drugs in traffic), Nederlands Tijdschrift voor Geneeskunde, 112, 1968, pp. 1862-1868; F. A. Nelemans, Geneesmiddelen en Verkeersongevallen (Drugs and traffic accidents), Geneesmiddelenbulletin, 1, 1967, pp. 9-12; C. Medawar, Power ^ (London: Social Audit, 1992), pp. 80-92.

76. S. L. Speaker, From 'happiness pills' to 'national nightmare': changing cultural assessment of minor tranquillizers in America, 1955-1980, Journal of the History of Medicine, 52, 1997, pp. 338-376, 350; H. M. van Praag, Psychofarmaca. Een Leidraad voor de Praktiserend Medicus (Assen: Van Gorcum \& Co., 1966), p. 114.

77. Speaker, op. cit., Ref. 76, pp. 349-355.

78. Pieters \& Snelders, op. cit., Ref. 67.

79. Wesson \& Smith, op. cit., Ref. 38, pp. 15-17; Pohlisch \& Panse, op. cit., Ref. 41, pp. 14-16; Sneader, op. cit., Ref. 43, p. 366.

80. J. Abraham \& J. Sheppard, The Therapeutic Nightmare (London: Earthscan, 1999).

81. J. Te Lintelo \& T. Pieters, Halcion: De lotgevallen van de 'Dutch Hysteria', Pharmaceutisch Weekblad, 41, 2003, pp. 1600-1605. 
82. J. Melville, The Tranquillizer Trap and How to Get Out Of It (Glasgow: William Collins, 1984), p. 18; J. Cooperstock \& J. Hill, The Effects of Tranquillization: Benzodiazepine Use in Canada (Ottawa, ON: Health and Welfare Canada, 1982); Tone, op. cit., Ref. 66, p. 379; Deutsche Hauptstelle gegen die Suchtgefahren, Medikamentenabhängigkeit: Eine Information für Ärzte (Hamm: Aschanbah Druck, 1984).

83. J. A. Haafkens, Rituals of silence: long-term tranquillizer use by women in the Netherlands, $\mathrm{PhD}$ thesis University of Amsterdam, 1997, pp. 5-7.

84. J. Gabe \& M. Bury, Tranquillisers as a social problem, The Sociological Review, 36, 1988, pp. 320-352;

J. Gabe, Understanding Tranquillizer Use: The Role of the Social Sciences (London, Tavistock, 1991);

J. Gabe \& M. Bury, Halcion nights: a sociological account of a medical controversy, Sociology, 30, 1996, pp. $447-469$.

85. Gezondheidsraad: Kerncommissie MTA, Naar een Doelmatig Gebruik van Benzodiazepines (Towards an Efficient Use of Benzodiazepines) (Den Haag: Gezondheidsraad No. 20, 1998).

86. Haafkens, op. cit., Ref. 83, pp. 5-7.

87. J. E. Gadsby, Addiction by Prescription (Toronto: Key Porter Books, 2000), p. 19.

88. For example, see http://o.webring.com/hub?ring=benzo (accessed 18 April 2006). 